The Geographical Journal of Nepal

Vol. 15: 63-82, 2022

DOI: https://doi.org/10.3126/gjn.v15i01.42887

Central Department of Geography,

Tribhuvan University, Kathmandu, Nepal

\title{
Reflection of nature in the material culture of the Karbi tribe: A case from Kamrup (M) district, Assam, India
}

\author{
Barasha Rani Das $^{1^{*}}$, N. Deka², A. K. Bhagabati ${ }^{2}$ \\ ${ }^{1}$ Department of Geography, Sibsagar Girls' College, Sivasagar, Assam, India \\ ${ }^{2}$ Department of Geography, Gauhati University, Guwahati, Assam, India \\ *Corresponding author: barashad110@gmail.com
}

Received: 13 October, 2021; Accepted: 12 November, 2021; Published: March, 2022

\begin{abstract}
The processes of nature-culture interaction and resulting landscapes in an area form fertile fields for geographical research. The present study is an attempt to analyse the reciprocal relation between people and nature in a tribal village environment of the Brahmaputra Valley, Assam. Based on intensive field survey and interviews with the inhabitants, the study reveals that the human-environment relationship in the village is still mutually helpful and more or less sustainable. However, perceptible changes have occurred in the traditional cordial relationship between the people and their environment in respect of habitat, economy and mode of living mainly due to the growing influence of modernization.
\end{abstract}

Keyword: Nature-culture interaction, material culture, environment, rural landscape.

\section{Introduction}

The broad cultural landscapes of the Brahmaputra Valley, Assam are basically the mosaic of ethnic cultural elements that evolved through interaction with its diverse physical settings (Deka and Bhagabati, 2010). The indigenous tribal and non-tribal ethnic groups with their respective cultural backgrounds have used the natural resources sustainably and thus given rise to some distinctive cultural elements in the Valley (Deka and Bhagabati, 2015). The culture and the associated natural settings shared by the ethnic communities are intrinsically linked, and this kind of bond between them is the product of their reciprocal response to each other (Hartel et al., 2014; Kizos, et al., 2010; Nassaue, 1997). 
The ethnic communities through their varying responses to the local environment have developed diverse land use patterns and eventually created some indigenous landscapes in different parts of the Valley (Tadaki et al., 2011; Deka, et al., 2011).

It has been observed that the interplay between nature and culture in the rural areas of the Brahmaputra Valley in the past had been intimate and very intrinsic (Deka, 2012). Nature supported the early inhabitants of the Valley generously providing all the required commodities. Being the fundamental determining factor, nature plays an important role in directing and shaping the culture of the communities living in the villages of the Valley.

Similarly, culture also performs its own role in reshaping nature providing thereby opportunities for cultural reproduction (Amanat, 2016; Bennett, 1994; Goode, 1904). Like other traditional rural societies, the dwellers of the Brahmaputra Valley have also been using the natural resources simply to fulfill their daily needs and necessities without degrading much their local environment (Saikia, 2011; Deka, et al., 2011; Saha, 2016).

During the recent years, the modification of the physical environment to fulfill human demands has put the man-environment relationship in a critical state (Arnold and Guha, 1995; Gadgil and Guha, 2000; Khan, 2015; Ellis et al., 2000). This has created a new interface between human and nature for which all kinds of modern social processes, such as rapid population growth, urbanization, industrialization, globalization are generally held responsible (Schimel, et al., 2007; Gu and Subramaniam, 2014; Primdahl and Swaffield, 2010; Kizos, et al., 2010; Amanat, 2016). These processes driven primarily by irrational and selfcentric human activities have remoulded the cordial relation between human and environment to be a 'hostile' one leading the primitive 'biological man' to transform into an 'economic man' thereby bringing a paradigm shift in the idea of human-environment relationship (Singh, 2014; Haila, 2000).

The co-existing nature of relationship between people and environment in the rural areas of the Brahmaputra Valley, Assam has also undergone remarkable change during the recent period leading to some significant transformations in the traditional rural landscapes (Saha and Deka, 2018). The rural communities of the Valley also at the same time have experienced changes with respect to their livelihood pattern, social relation, traditional belief system, attitude, occupational structure and so on (Saikia, 2007). 
Importantly, there are still some remote areas, where the transport and communication system is yet to be improved. In such areas, the nature-culture interaction is found to be very cordial and the natural environment continues to determine the life and living of the people in those areas (Bhandari, et al., 2018; Das, 2020). Although the socio-economic condition of these people is not comparable with that of the urban or sub-urban dwellers, there are people who are living peacefully with accommodative response to their immediate natural environment. The present work is basically an attempt to investigate the role of natural elements in shaping the traditional material culture and how the recent changes have affected the traditional use of the artifacts in the context of an ethnic village called Magursila located in the Kamrup (Metro) District of Assam, India.

\section{Methods and materials}

At a time, when in many parts of the Brahmaputra Valley, the interventions of the modern social processes have degraded the rural ecology, the Karbis, an indigenous tribal community living in the hills and plateaus of Assam, still manifest certain interesting facts about their traditional response to the natural environment. Located in the Brahmaputra Valley and inhibited by the Karbi community, Magursila village has been selected for the study as it provides immense scope to analyse how the material culture of the villager is deeply embedded in the natural setting of the area, even in the current period of rapid social change and development.

The village is located in the Sonapur Revenue Circle of Kamrup (Metro) District of the Brahmaputra Valley, Assam (Figure 1). The village lies within $26^{\circ} 03^{\prime} 12.20^{\prime \prime} \mathrm{N}$ to $26^{\circ} 04^{\prime} 39.29^{\prime \prime} \mathrm{N}$ latitude and $91^{\circ} 59^{\prime} 35.42^{\prime \prime} \mathrm{E}$ to $92^{\circ} 02^{\prime} 8.64 " \mathrm{E}$ longitude. It is a typical Karbi village covering an area of nearly 4.5 sq.km with a population of 653 as per 2011 Census. It is located at a distance of about $30 \mathrm{~km}$ from the district headquarter and State capital Guwahati. The village comprises of 4 chuburis (hamlets) with a total households of 126. Its natural landscape is characterized by dense forest cover, streams and dongs (canals). Although located within Kamrup (Metro) District, the village is fairly away from the direct influence of modern developmental processes. Thus, the people of the village are still living a traditional life by maintaining a harmonious relationship with its immediate natural environment. 


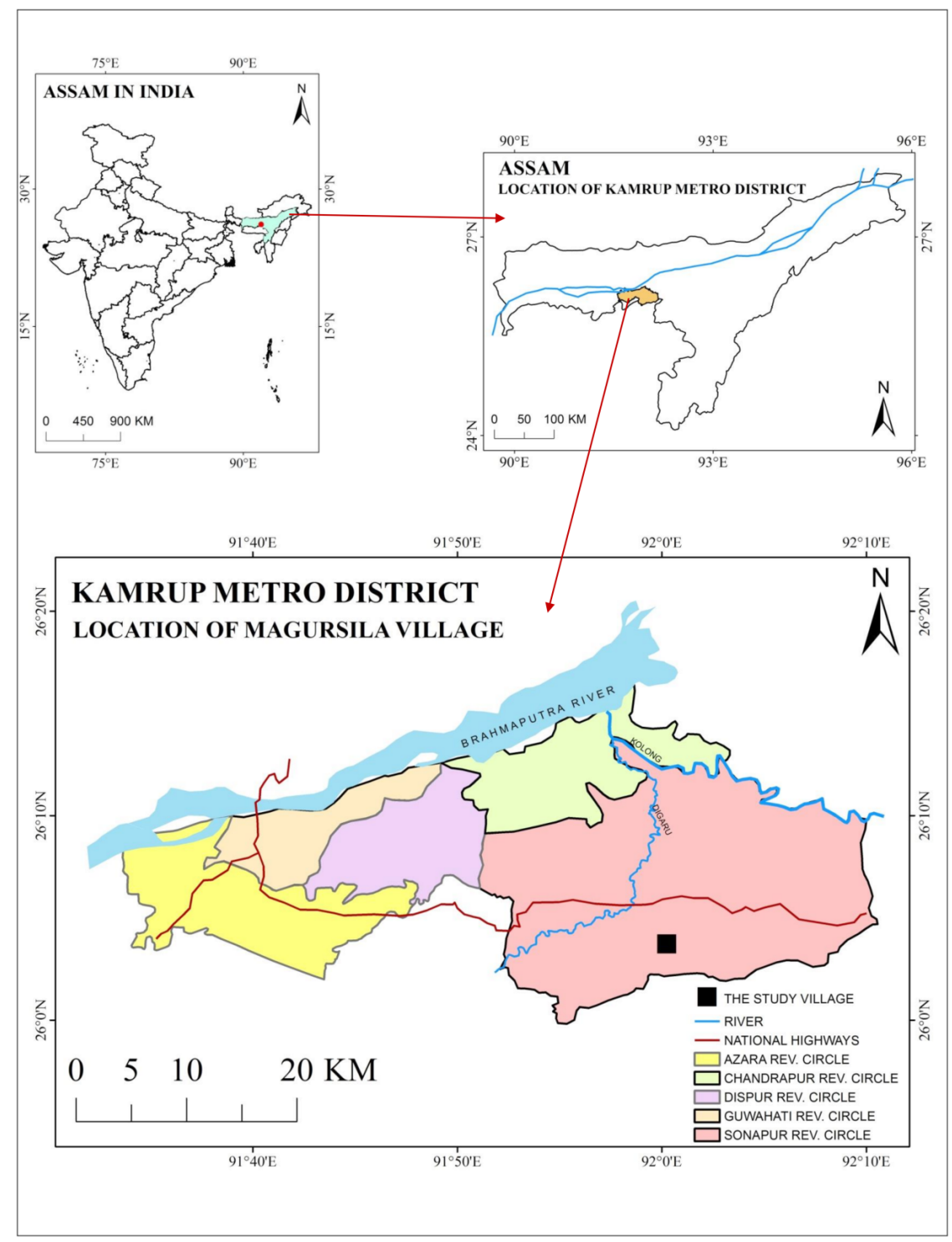

Figure 1: Location of the village in Kamrup, Assam

The study is mainly based on primary data and information collected through a well designed questionnaire-cum-schedule and personal observations in the field. The village was intensively surveyed covering all the 126 households during 2018-2019. Data and information on certain trees grown as a part of 
agro-forestry, household assets possessed and materials used by the villagers were collected using survey schedule and oral interview with the village people. Moreover, some of their socio-cultural activities/ceremonies were observed through direct participation. Seasonal changes in the village landscape as well as involvement of the villagers in different seasonal activities were also carefully observed through personal visits to the village in different climatic seasons. Focus Group Discussions (FGD) among three different groups of people- elderly people, women and youths - were conducted to acquire information on the pattern of nature-culture interaction in the past, reflection of nature in the dresses and ornaments used by the women folk, kitchen environment, perceptions of the youths towards the natural landscapes and their change over time and future prospects. Besides, information related to various house-building materials, traditional fishing gears, agricultural tools etc. were gathered to analyze the role of the ecosystem in the life and culture of the villagers.

As the village is a non-revenue village, cadastral map is not available. Therefore, sketch maps were prepared with the help of Participatory Rural Appraisal (PRA) method and ground survey using GPS. The circle map collected from the Sonapur Revenue Circle Office was used to show the location of the village using ArcGIS 9.2 software. Some cartographic and quantitative techniques and softwares like MS Excel were used for processing and representing the data obtained from the field. Moreover, relevant photographs were taken and documentation of certain physio-cultural aspects was made in order to authenticate the findings.

\section{Results and discussion}

\section{Nature-culture interaction}

The 'nature-culture' interaction basically refers to the relationship between the physical elements and human culture in an area which is constantly coevolving, making them practically inseparable (Fuentes, 2010; Haraway, 2003; Folke, 2006; Liu, et al., 2007). Nature has always been effective in all aspects of human life and livelihoods and thus it plays a dominant role in shaping the culture of the people sharing it (Salman and Munir, 2016; Thakur, 2018).

Human culture in different parts of the world is the outcome of man's response to the physical environment on the one hand and the influence of nature on the human society on the other. Based on their needs and aspirations, human beings have been utilizing various types of natural resources and thus create distinctive cultural milieu in the concerned areas (Goode, 1904). 
The rural cultural landscapes of the Brahmaputra Valley, Assam have also been the product of man's persistent interaction with the natural setting. This is visibly reflected in the land use and settlement pattern, house type, food and dress habit and the overall mode of living of the people (Deka, et al., 2011). In the village under study, the long continued human interaction with the natural environment has resulted in a cultural landscape specific to the village environment (Figure 2). There has been a perceptible conformity between the natural features like topography, forest cover and drainage and the man-made elements like settlements, houses, roads and agricultural fields. Such an ecofriendly response of the people to their environment basically characterizes the village landscape. The cultural landscape of the village is thus the product of the prevalent subsistence economy, indigenous knowledge, perception and attitude of the people living in the area. The pattern of land use and land cover, type of house, mode of production and occupational structure, among others, visibly reflect the adaptation of the people to their natural environment.

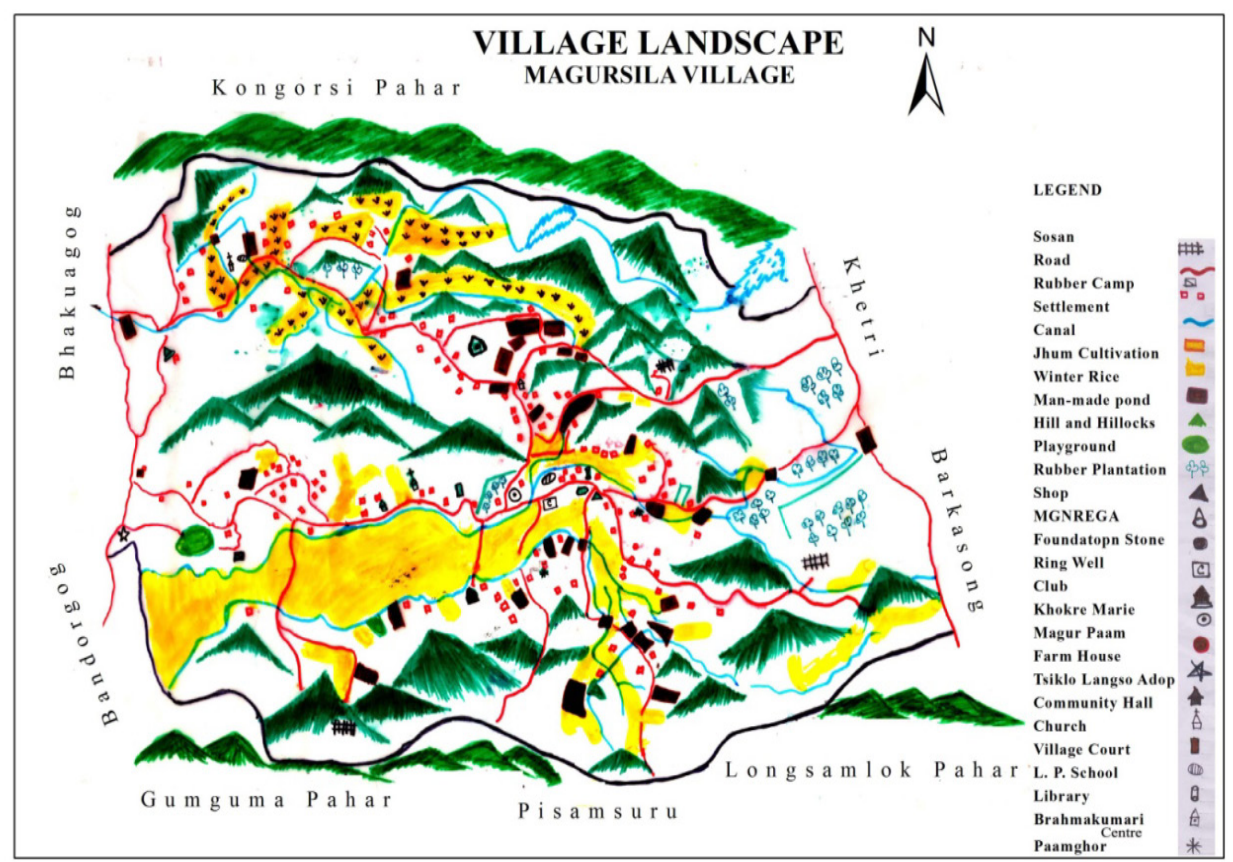

Figure 2: Landscape of the village 


\section{Reflection of nature in material culture}

The people living in the hilly areas of the Brahmaputra Valley, particularly the Karbis, who depend mainly on the forest resources for their daily needs, have been maintaining so far a balanced relationship with nature (Sarma and Barpujari, 2011). They have developed certain attractive cultural landscapes in the hilly environment within the Valley (Deka, et al., 2011). The Karbi people of the village under study are largely dependent on some ecological resources to fulfill their daily needs and thus have developed a variety of cultural elements specific to this community and the local environment. Their relative isolation, tradition, community perception and living with nature kind of attitude have made them apparently distinct from the neighbouring non-tribal communities.

\section{House type and building materials}

Natural products are generally used in the construction of folk houses. The houses of various types constitute a notable component in the rural cultural landscape. Like other rural areas of the Brahmaputra Valley, the people of this village also use various locally available natural products in constructing their houses. Elements of a house like khuta (post), borkhuta (main post), roof, door, boundary fencing are constructed using different species of bamboo, tree, and thatch which they can easily gather from the immediate environment. To construct the posts of a house, various species of bamboo such as Jati baah (Bambusa tulda), Bhaluka baah (Bambusa balcooa) are used. However, the main post (Kardong-aarmuk) is constructed using locally available tree species like Sonaru (Cassia fistula), Segun (Tectona grandis) and Churtum. Faalang thatch and rice straws are generally used as roofing materials (Photograph 1 and 2). Moreover, the materials used in preparing Jingta (a strip of green bamboo) include bono baah, ingren (a creeper), Khambi - aaringkang (Khilagos), Sikongaari etc., while Jatibaah and Bijuli baah (Bambusa pallida) are used in preparing different stakes (khuti) required to build traditional houses. Moreover, the boundary fencings are erected using dolo baah, ekora and betel-nut leaf. 

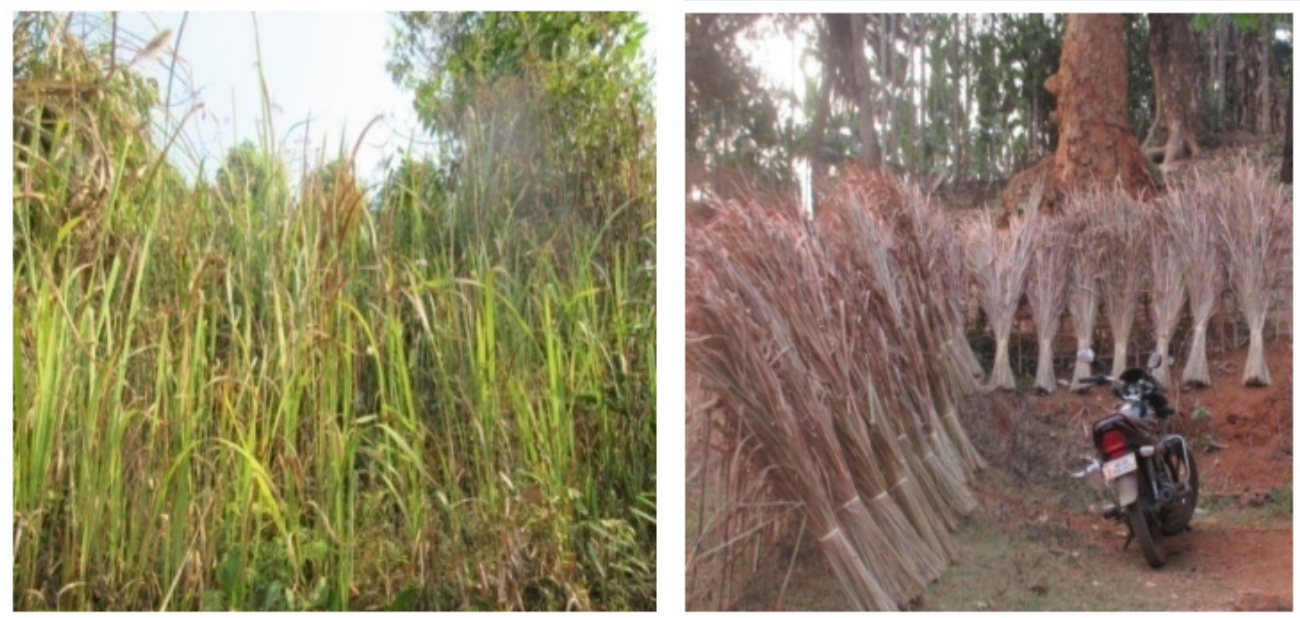

Photograph 1 and 2: Faalang thatch used for roofing

\section{Folk musical instruments}

Folk musical instruments play an important role in the lives of the Karbis. These are developed and used by the community and usually do not have known inventors. Karbi folk instruments are generally made of some bamboo and tree species. Musical instruments have a notable place in the festivals and ceremonies celebrated by the Karbi community (Photograph 3). The use of natural products mainly bamboo, gomari, poma and udaal trees in preparing musical instruments is noteworthy. An important musical instrument of the Karbis called Cheng played in various cultural occasions and festivals such as Domahi (Bihu), Dehal Puja, harvesting of jhum crops, death ceremony, installation of Numpe-aarmuk (main wooden post of a house) and Tike Kikaan is made of gomari (Gmelina arborea), poma (Toona ciliate), looring tree, jute and udaal tree available in the village environment. Moreover, while performing any Karbi song and specially on the occasion of Moi Moi kikaan, the villagers play another important instrument called pongsi (a kind of flute), which is made of locally available dolobaah (Tereng in Karbi). Besides, Geng-geng made of gomari wood is used in performing traditional songs by the villagers. Apart from these, other important musical instruments used by the Karbis of the village include pongsi, moori, Krongso and sere/haarling, which are prepared from different types of bamboo collected from the hills of the village. 

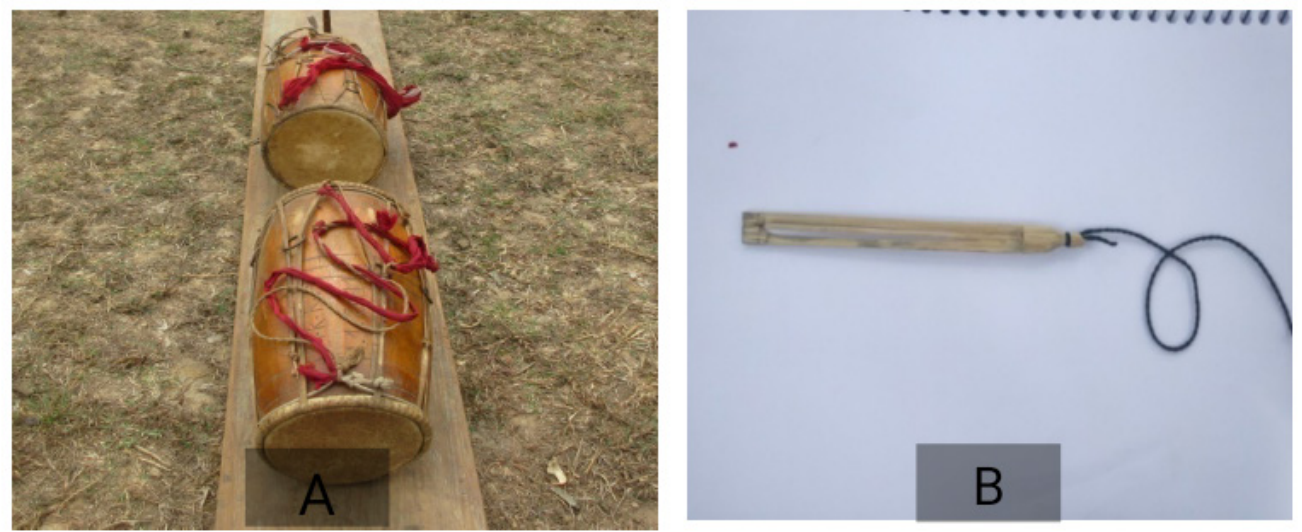

Photograph 3: Traditional musical instruments A-Cheng; B-Krongso

\section{Traditional costumes}

The traditional dress pattern of the Karbis has a close relation with their local ecological conditions (Teron and Borthakur, 2012). The villagers traditionally prepare their cloths from raw cotton produced in the village (Photograph 4 and 5). However, now-a-days they procure cotton threads from the markets as the cotton plants available in the village are not sufficient to fulfill the growing demand for threads. Moreover, preparation of cotton threads manually is a time consuming process.

As stated by the elderly people of the village, the blue colour of their traditional dresses, which is a community choice as the purest colour, is prepared from a plant locally known as Chubu (Justician latispica). First, the leaves and flowers of this plant are processed with the help of some grinding tools like urol and $d h e k i$ and then the fluid part of the paste is separated and is mixed with khaar. In this mixture, cotton threads are shocked for a few days. Once these are properly soaked, the threads are dried up under sunlight. Finally, the homemade bluecoloured cotton threads are set for weaving new clothes. However, presently, the number of people using this plant species for thread colouring has declined due to the availability of processed threads. It is thus to be noted that the Karbis traditionally possess knowledge and skills for preparing herbal dyes for colouring their cloths (Teron and Borthakur, 2012).

Interestingly, some of the villagers rear Eripolu (silkworm) from which they manually prepare Eri silk. It is thus observed that the ecological elements play 
an important role in the preparation of traditional dresses used by the people. All these reflect an intimate relationship between the ecology and human culture in the Karbi village. The people of the village put various motifs in their dresses through replication of biotic elements like spider, wildflowers, insects, deer, etc. These elements are integral parts of the local ecosystem (Photograph 6).
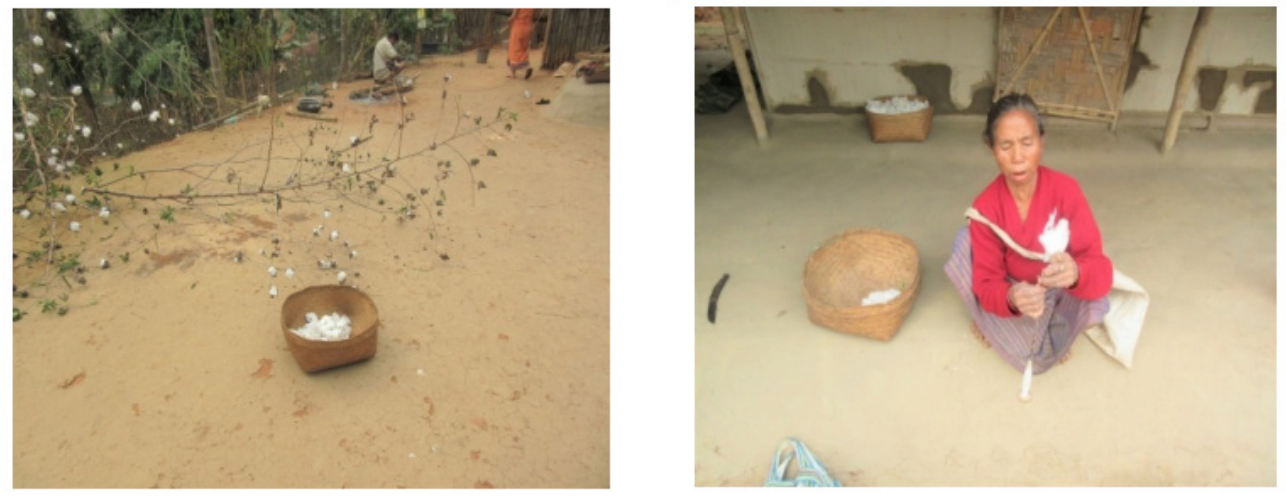

Photograph 4 and 5: Preparation of cotton threads from raw cotton
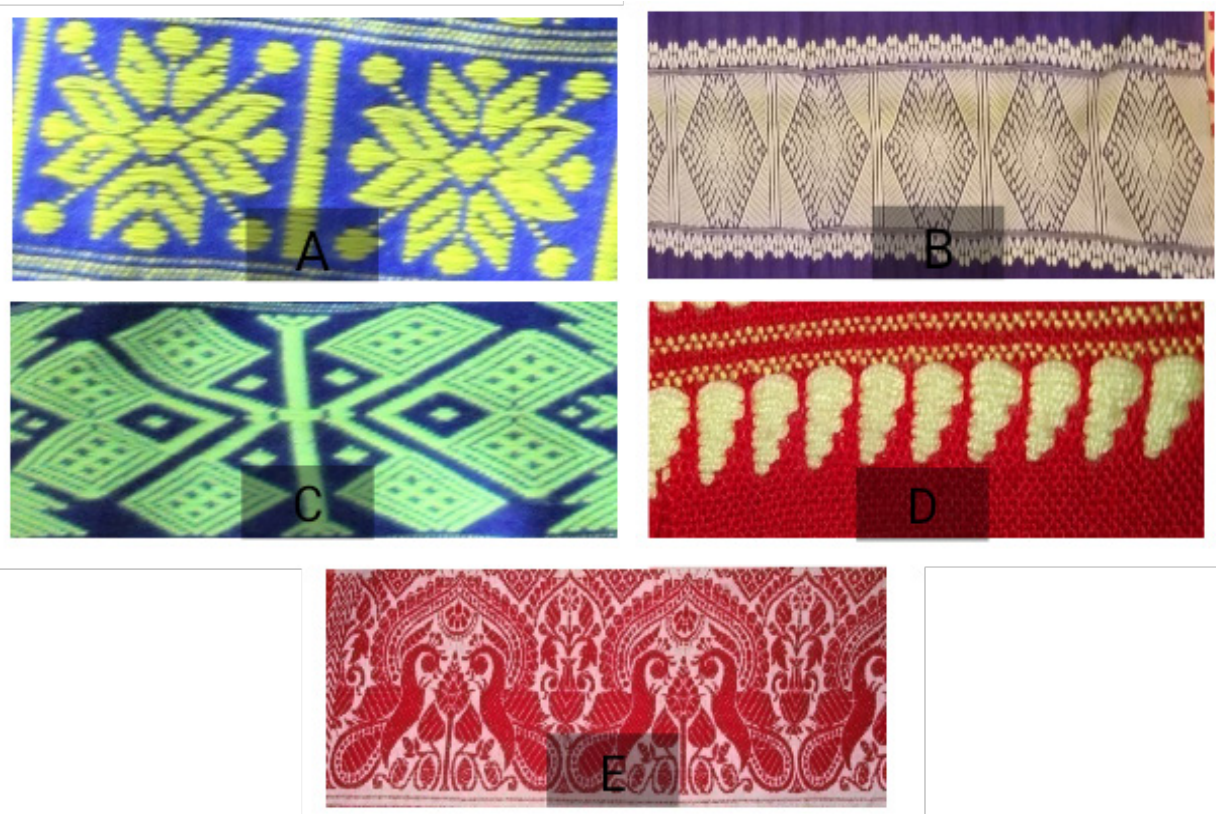

Photograph 6: Motifs inscribed in traditional dresses A- wild flower; B- grass; Cbisoni (hand fan); D- kaachi; E-peacock 


\section{Fishing gears}

Fishing is a very popular activity among the Karbis. Fishing activities having notable economic and cultural significance play an important role as a livelihood option particularly for the weaker section. Traditionally, both males and females engage themselves in fishing in the rivers, springs and other wetlands present in their locality. Therefore, they have acquired knowledge and skills through generations to prepare a variety of fishing tools (Photograph 7). The use of various species of bamboo like jatibaah, bono baah, bijuli baah in preparing fishing gears in the village is remarkable. The traditional fishing gears such as jaakhoi, polo, boo bo, rooh, sorha and buhri, which are mainly made of bamboo keeping in view the size and behavior of the fish varieties, reflect the significance of ecosystem in the folk cultural expressions of the Karbi community.
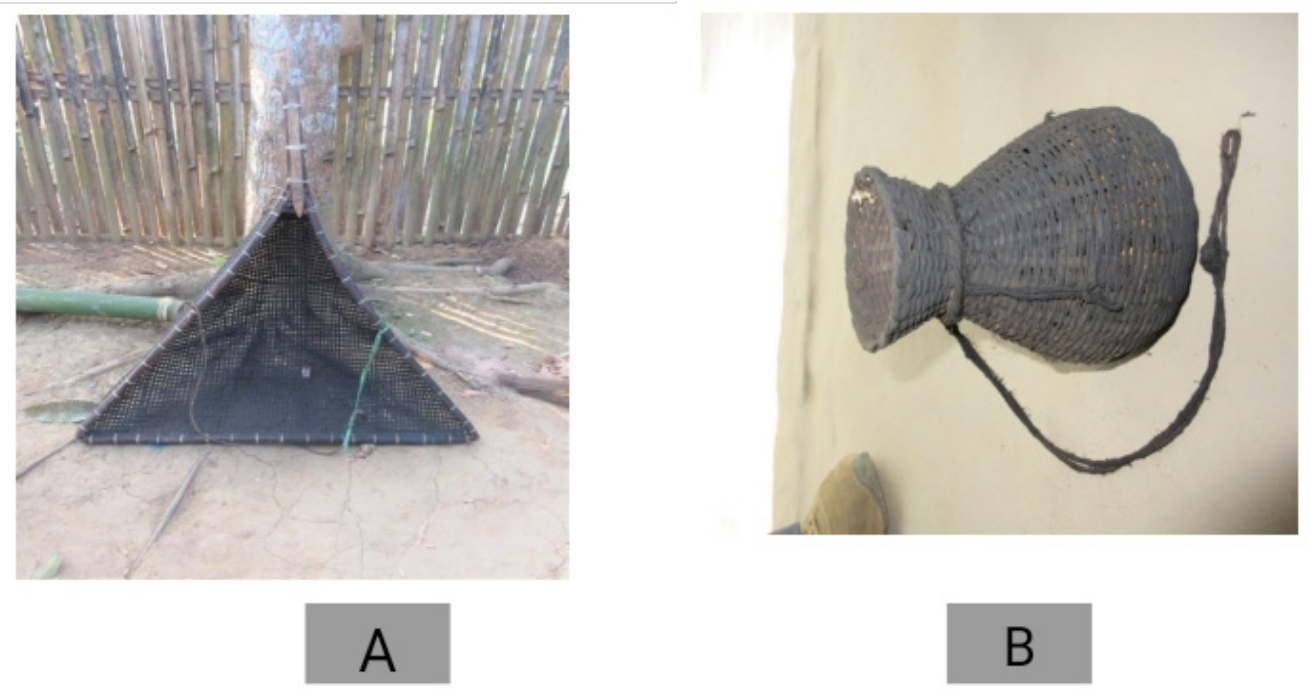

Photograph 7: Traditional fishing gears A-Jaakhoi; B- Boo Ho

There are a number of water bodies in and around the village which include streams, man-made dongs (diverted water flow) and ponds. All these provide a variety of fish to the villagers for their domestic consumption and also for sale. However, natural fish varieties are now declining in number and the villagers are increasingly interested in raising cultured fish mainly carps in their ponds. The ponds of different sizes and depths have now become the characteristic feature of the village landscape. This has affected the use of traditional fishing gears among the villagers. 


\section{Kitchen utensils}

A separate house or a small part of the main house is generally used by the Karbis as their kitchen. The kitchen itself and the utensils used in cooking process bear the imprints of the traditional culture and food habits of the community. The utensils used by the villagers are made of the natural objects available in the village. Though they have now started using different types of plastic or steel utensils in their kitchens, yet the traditional bamboo-made or wooden utensils still continue to dominate their kitchen activities. The villagers themselves prepare utensils mainly from different bamboo species and also from some trees like gomari and kothal (Photograph 8). Some traditional kitchen utensils used by villages are noted below:

(a) Choba: A traditional kitchen utensil made of gomari tree is used to serve cooked rice among the family members. This utensil is now rarely used by the villagers.

(b) Aanchoho: It is a rice measuring implement basically made of bonoria baah (wild bamboo).

(c) Bolong Cher: Made of dolo baah, it is used to filter out traditional home-made soda.

(d) Chi: It is used to filter out the traditional alcoholic beverage locally called hor.

(e) Choroh: A tool usually made of gomari and kothal(Jackfruit) tree, is used to serve hor (local beer).

(f) Laanghan: Made of bono baah, it is used to drink hor or water.

(g) Phelep: Phelep is a traditional food preparing tool made of bamboo.

(h) Thumphla: Made of all types of bamboo, it is used to stir a food item.

Besides the above, the leaves of a plant species called luru (Phrynium pubinerve) are used as platter to carry cooked rice to the agricultural fields and also to the hills where from people collect various food items like banana, kolphul, dhekia, paanilau, rongalau, mitha-aalu etc. The influence of market economy has, however, considerably changed the kitchen environment of the Karbis during the recent period. 

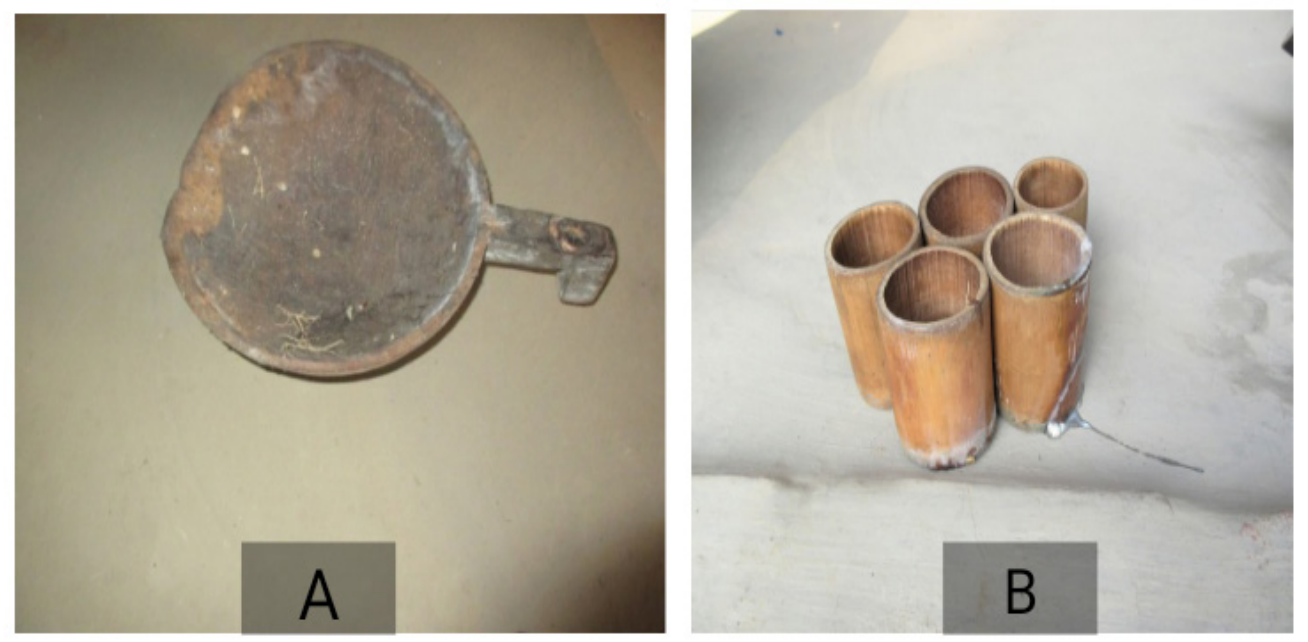

Photograph 8: Traditional kitchen utensils used by the villagers A-Choba; B-Laanghan

\section{Agricultural practices}

In addition to the above mentioned traditional skills and materials, the reflection of nature is also worth noting in the agricultural practices carried out by the villagers. The villagers ( $98 \%$ of the male workers) have been traditionally performing their agricultural activities based on organic agricultural inputs and implements. The local crop varieties, traditionally designed agricultural tools, cropping pattern and practices are found to have close attachment to the culture of the Karbi community. Interestingly, with the growth of literacy rate (57.23\% literate), educational attainment and influence of the market forces, some changes in the agricultural practice have been observed. Now-a-days, people are increasingly inclined towards using chemical fertilizers, pesticide and insecticides. Some of the traditional agricultural tools (Photograph 9) commonly used by the people of the village are as follows:

(i) Naangol: A bullock driven wooden tool used for ploughing.

(ii) Xola: Made of locally available Bijulibaah, it is used to carry home the harvested crops.

(iii) Moi: A bullock driven bamboo-made tool used for leveling and breaking soil clods.

(iv) Tingjor: It is used for digging soil to plant trees and crops. This tool is made of hardwood tree.

(v) Raalnik: A bamboo-made tool used for distributing water in the agricultural fields. 
(vi) Rena: It is used for scooping and overturning the seeds when they are put to dry up. It is made of locally available trees like gomari, xokhon and bamboo.

(vii) Kaamching: For raising dykes in the sali rice fields the villagers build 'kaamching' by using hard tree branches.

(viii) Sikia: It is used to carry large amount of rice, cow dung etc. to the agricultural fields.

(ix) Haak: Made of different species of bamboo, it is used to carry vegetables, fruits and other forest products from the nearby hills.
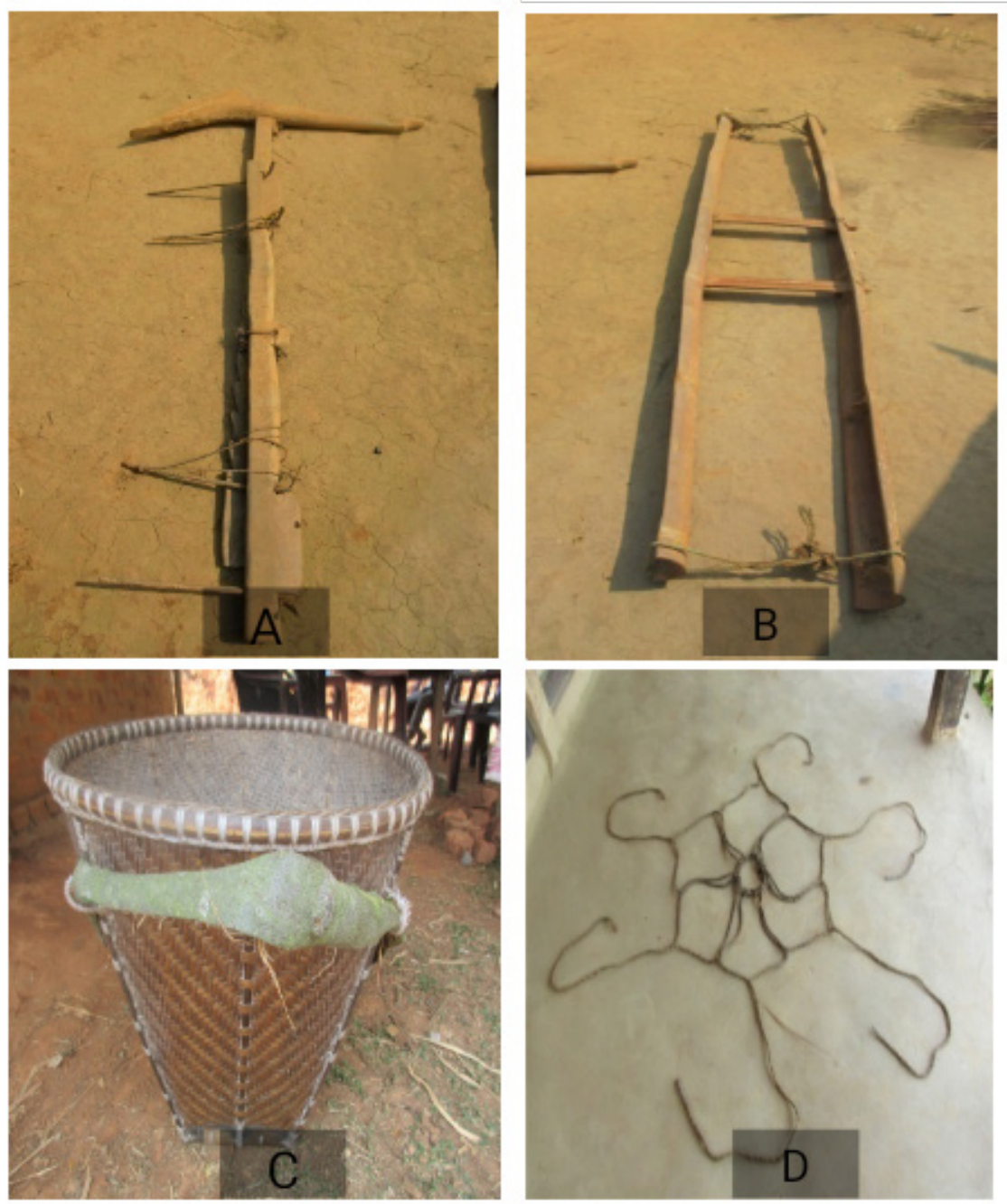

Photo 9: Agricultural tools A-Naangol, B-Moi, C-Haak, D-Sikia 


\section{Ethnic handicrafts}

The tribes of the Brahmaputra Valley including the Karbis have a rich tradition of preparing decorative materials out of the locally available resources, especially bamboo and canes. Applying their traditional knowledge and skills, the Karbis of the village under study continue to produce quality handicrafts that attract the attention of the people living in the neighbouring towns and villages. The bamboomade crafts carefully designed following the look and structure of certain local birds, animals and insects are really very interesting to note (Photograph 10). These handicrafts clearly reflect their intimate relation with the living elements of their habitats. That they are integral part of their ecosystem shared by them traditionally, is adequately demonstrated through their perception and material culture including the handicrafts.
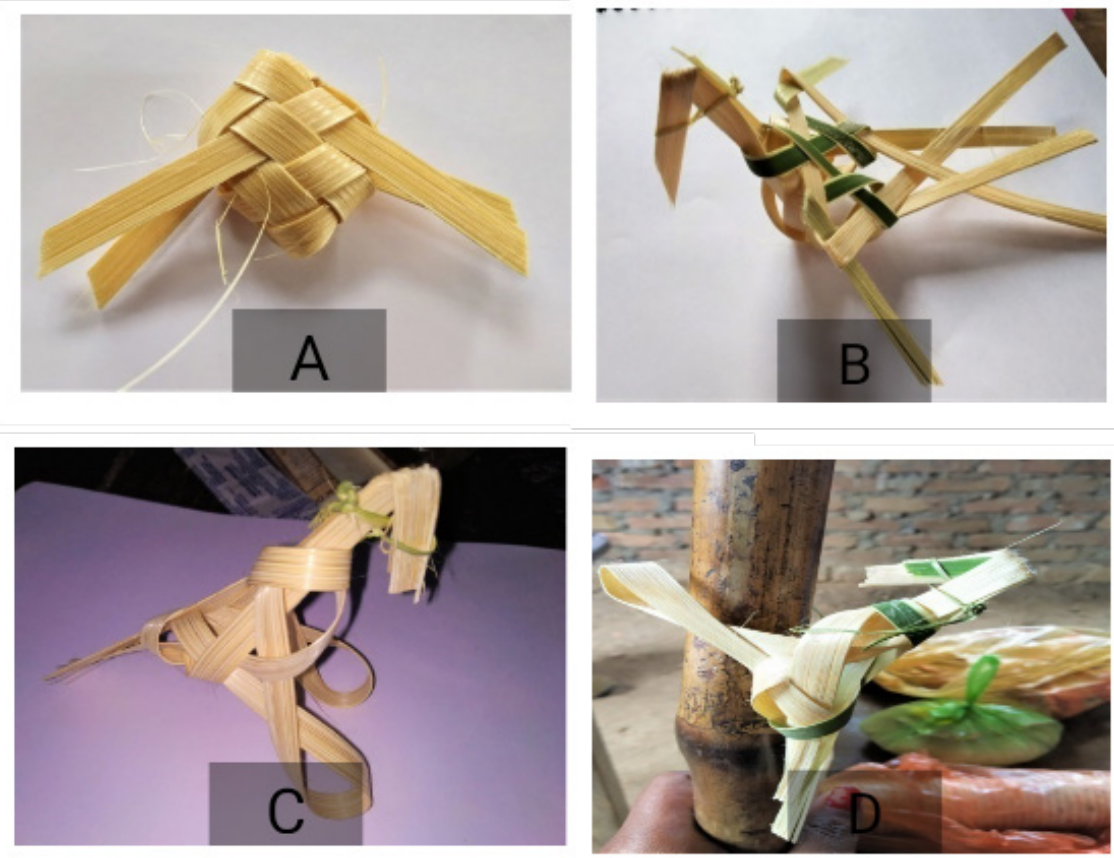

Photo 10: Some handicrafts prepared by the villagers analogous to A- insect, B- kupoti (dove), C and D Kathruka bird

\section{Socio-cultural transformation}

Every society naturally passes through an evolutionary process. Its associated landscapes also get transformed over time under the influence of modernization. In this village also, the in-road of modern socio-economic process has started transforming the socio- 
cultural landscapes of the village, which is adequately reflected in the declining use of traditional tools and knowledge system in different activities and collective decisionmaking.

The assimilation among the Karbi people of the village with the neighbouring Assamese society has promoted primarily the development of transport and communication in the area. This has resulted in socio-cultural transformation in the village life with respect to food habit, dress pattern, festivals and other socio-cultural practices (Phangso, 1989; Roy, 1999). It has been observed that most of the Karbi women, at present, wear Assamese costumes (mekhela-sador) on various cultural occasions and ceremonies (Das, 2020; Das, 2019). The males have also started wearing jeans pent, full shirts, t-shirts on such occasions. Importantly, school going children of the village have to wear uniform in their schools, which has significantly weakened their traditional dress habits.

The traditional agricultural practices have also experienced remarkable change during the recent years. The use of chemical fertilizers and pesticides has considerably degraded the natural soil fertility affecting the productivity of the traditional crops in the village. The crude agricultural tools are also getting increasingly replaced by the modern tools like power tillers, sprayers and so on. The agricultural fields are getting fragmented due mainly to the decline of the joint family system among the village community. Moreover, the increasing use of easily available ready-made food items has affected the traditional practice of collecting edible herbs and roots from the hills around.

The cooking process has also undergone some change. The use of mustard oil and spices in the preparation of food item has now become more or less common. The use of sunga (bamboo) for cooking food items is now replaced by karahi, an utensil durable enough and easily available in the local markets. Additionally, the traditional house building materials such as bamboo, wood, jute ropes, thatches, etc. are now being progressively replaced by modern building materials like bricks, sand, cement and tin. The thatch-roofed eco-friendly folk houses have been gradually replaced by tin-roofed pucca houses. At present, out of the total households of 126, only 11 households possess typical traditional houses, 66 households have tin and thatched roofed wooden houses and 49 households have tin-roofed pucca houses. Moreover, changes have also been observed among the villagers in the use of traditional fishing gears, musical instruments, kitchen utensils and so on. 


\section{Conclusion}

The nature-culture interaction in the rural environment has always been intensive as the economy and culture of the villages are directly related to the natural setup of the area. Nature is deeply rooted in the folk life and culture of the Karbi people living in the village. Their day-to-day life and traditional activities are overwhelmingly dependent on the natural resources available in their environment. They try to maintain an intimate and balanced relationship with nature as they are aware of the fact that nature continues to sustain their life and culture spontaneously. The reflection of nature in their folk culture is, therefore, very much prominent. However, like any other society, the ethnic life in this village has also started getting transformed under the influence of modern material culture. The influence of Guwahati city, which is located at a distance of $30 \mathrm{~km}$ only from the village, is also slowly gaining ground to affect the traditional life and living of the villagers. The spread of sub-urban transport and communication development has already reduced the time distance between the city and the village area. Interestingly, the changes already occurred in the traditional farming practice, green cover and housing in the village have now started affecting the ecological system of the village. Thus the emerging changes in the cultural landscapes will obviously overshadow the otherwise vibrant natural setting of the village. Therefore, maintaining a sustainable relation with nature is the need of the hour to ensure a mutually helpful nature-culture interaction, particularly in the less advanced tribal areas like the present one.

\section{References}

Amanat, A. (2016). Environment and culture: An introduction, Iranian Studies, Vol. 49, No. 6, pp. 925-941.

Arnold, D. \& Guha, R. (1995). Nature-culture imperialism: Essays on the environmental history of south Asia. Oxford University Press, Delhi, pp. 2-3.

Bennett, J. W. (1944). The interaction of culture and environment in the smaller societies. American Anthropological Association Vol. 46 Issue 4. pp. 461-478.

Bhandari, A., Khadka, U. R. \& Kanel, K. R. (2018). Ecosystem services in the midhill forest of western Nepal: A case of Panchase protected forest. Journal of Institute of Science and Technology. Vol. 23. pp. 10-17.

Das, B. R. (2020). Nature-culture interactions in an ethnic village of Kamrup (M) district, Assam: present status and future prospects. Unpublished M.phil dissertation. Gauhati University, Guwahati.

Das, M. (2019). Asomor jonogusthiyo saaj-paar aru geet-pod. Assam prakashan parishad. Guwahati, pp.1-67. 
Deka, N. (2012). Agroecosystems in the Brahmaputra Valley, Assam: dynamics and sustainability. Unpublished Ph.D thesis. Gauhati University, Guwahati.

Deka, N., Asada, H. \& Yamane, Y. (2020). Rural livelihoods and environmental changes in Muktapur village: People's voice. Shinohara printing Co. Ltd, Japan, pp.162.

Deka, N. and Bhagabati, A.K. (2015). Wetlands in a village environment: A case from Brahmaputra floodplain, Assam. Transactions, Institution of Indian Geographers Vol. 37. No. 1, pp. 34-45.

Deka, N. \& Bhagabati, A. K. (2010). Farming practice in a floodplain village of Assam (India): Continuity and change. Indonesian Journal of Geography. Vol 42, No. 1. pp. 13-34.

Deka, N., Bhagabati, A. K. \& Ando, K. (2011). Rural land use in Brahmaputra floodplain environment, Assam: A case of Muktapur village. Contemporary India. Vol. 1. pp. 177-193.

Ellis, E. C., Neerchal, N., Peng, K., Xiao, H.S., Wang, H., Zhuang, Y., Li, S.C., Wu, J.X., Jiao, J.G., Ouyang, H., Cheng, X. \& Yang, L. (2009). Estimating longterm changes in China's village landscapes. Ecosystems Vol.12. pp. 279-297.

Gadgil, M. \& Guha, R. (2000). The use and abuse of nature. London, p. 213.

Goode, J. P. (1904). The Human response to the physical environment. The Elementary School Teacher Vol. 4. No. 5, pp. 271-282.

Gu, H. \& Subramaniam, S. (2014). Drivers of change in socio-ecological production landscapes: Implications for better management. Eecology and Society Vol. 19(1). No. 1, pp. 1-13.

Haila, Y. (2000). Beyond the nature-culture dualism. Biology and Philosophy Vol. 15. pp. 155-175.

Hartel, T., Fischer, J., Câmpeanu, C., Horcea-Milcu, I., Hanspach, J., Fazey, I. \& Fischer, J. (2014). The importance of ecosystem services for rural inhabitants in a changing cultural landscape in Romania. Ecology and Society vol. 19(2).

Khan, K. (2008) Ecology and environmental management in Dehradun district. Unpublished Ph.D thesis, Aligarh Musilm University, Aligarh, Uttar Pradesh.

Kizos, T., Primdahl, J., Kristensen, L. \& Busck, A. (2010). Introduction: landscape change and rural development. Landscape Research Vol. 35. No. 6. pp. 571576. 
Nassaue, J. I. (1997). Placing nature culture and landscape ecology. Ireland press, first edition. pp. 4-179.

Phangso, P. C. (1989). The Karbis: A spatio -temporal analysis in tribal geography. Unpublished Ph.D. Thesis. Gauhati University, Guwahati.

Primdahl, J. \& Swaffield, S. (2010). Globalisation and rural landscape change - key concepts, development trends and some implications for policy. Estudosregionais No. 20, pp. 61-73.

Roy, B. G. (1999). A study on social change and its impact on tribal women of KarbiAnglong district of Assam. Unpublished Ph.D thesis. Gauhati University, Guwahati.

Saha, S. \& Deka, N. (2018). Evolution of landscape in a floodplain village of the Brahmaputra Valley, Assam. Indian Journal of Landscape Systems and Ecological Studies Vol. 41. No. 1, pp.120-132.

Saha, S. (2016). Landscape in a floodplain village of the Brahmaputra Valley, Assam: Evolution, change and sustainability. Unpublished M.Phil dissertation., Gauhati University, Guwahat., pp. 1-32, 60-90.

Saikia, A. (2011). Forests and ecological history of Assam. 1826-2000. Oxford University press. New Delhi.

Saikia, S. Y. (2007). A Study of the changing social system of the Karbis of Guwahati. Unpublished Ph.D thesis. Gauhati University, guwahati.

Salman, M.S. \& Munir, A. (2016). Common land resources, livelihood and sustaining the rural poor in India: A geographical analysis. European Journal of Geography Vol. 7. No. 4. pp. $6-18$.

Sarma, U. K. \& Barpujari, I. (2011). Eco-cosmologies and biodiversity conservation: Continuity and change among the Karbis of Assam. The International Indigenous Policy Journal Vol. 2(4). pp. 1-10.

Tadaki, M., Salmond, J., Le Heron, R.L. \& Brierley, G. (2011). Nature, culture, and the work of physical geography. Transactions of the Institute of British Geographers. Vol. 37.

Teron, R. \& Borthakur, S. K. (2012). Biological motifs and designs on traditional costumes among Karbis of Assam. Indian Journal of Traditional Knowledge Vol. 11 (2). pp. 305-308. 
Barasha Rani Das, N. Deka, and A.K. Bhagabati Reflection of nature... Vol. 15: 63-82, 2022

Teron, R. and Borthakur, S. K. (2012). Traditional knowledge of herbal dyes and cultural significance of colors among the Karbis ethnic tribe in Northeast India. Ethnobotany Research and Applications Vol. 10. pp. 593-603.

Thakur, N. (2018): River Song: Caste and cultural assimilation in the Brahmaputra river Valley, Assam. Ancient Asia Vol. 9. pp. 1-7. 